\title{
Chemical Constituents and Comparative Toxicity of Aspilia africana (Pers) C. D ADAMS LEAF Extracts Against Two Leafspot Fungal Isolates of PAW-PAW (Carica papaya L.)
}

\author{
E. M. Ilondu* \\ Department of Botany, Delta State University, PMB 1, Abraka, Nigeria; martinailondu@yahoo.co.uk
}

\begin{abstract}
The toxicity of chloroform, Petroleum ether and Methanol leaf extracts of Aspilia africana against Collectotrichum gloesporiodes and Curvularia lunatus, the pathogens of leafspot disease of paw-paw was investigated. The fungi were cultured in potato dextrose-leaf extract agar medium at the concentrations of $20 \mathrm{mg} / \mathrm{ml}, 40 \mathrm{mg} / \mathrm{ml}, 80 \mathrm{mg} / \mathrm{ml}, 160 \mathrm{mg} / \mathrm{ml}, 320 \mathrm{mg} / \mathrm{ml}$ and the mycelial extension growth rate were observed. All the extracts showed significant $(p<0.05)$ activity and concentration-dependent growth inhibition against the leafspot fungi with the percentage inhibition range from $35-100 \%$ at various concentrations. Only methanol extract gave $100 \%$ inhibition of fungal growth at $160 \mathrm{mg} / \mathrm{ml}$ and $320 \mathrm{mg} / \mathrm{ml}$. C. lunatus was more sensitive to the extract than C. gloeosporioides. Preliminary phytochemical screening of the extracts revealed the presence of alkaloids, anthraquinones, flavonoids, glycosides, phenols, saponins, tannins and terpenes in varying degrees. Gas Chromatography-Mass Spectrometry (GC-MS) analysis of the extracts showed a complex mixture of compounds which included 8 in methanol and petroleum ether extracts and 7 in chloroform extract. The implication of these findings is that extracts of $A$. africana could be a good antifungal agent with potential applications in agriculture against foliar diseases of paw-paw so as to improve production.
\end{abstract}

Keywords: Chemical Constituents, Antifungal Activity, Aspilia africana, Leaf Extracts, Leafspot Fungi, Carica papaya.

\section{Introduction}

Paw-paw (Carica papaya L) is a semi-woody tropical herb belonging to the family Caricaceae. It is the most important species within the Caricaceae family and generally grown from seeds for consumption as a fresh fruit commercially and in home gardens [1]. Paw-paw is the third most important horticultural fruit consumed in Nigeria after Citrus and plantain [2]. Paw-paw fruit is highly nutritive, low in calories and rich in natural minerals and Vitamins A, B, $\mathrm{C}$ and G. Ripe fruits are also used in Salad, juices, jams, candies or may be sliced and used as crystallized fruits [3].
The comparative calories content $(32 \mathrm{Kcal} / 100 \mathrm{~g}$ of ripe fruit) makes it a favorite fruit for obese people who are into weight reducing regime [4].

The fruits also contain papain, a proteolytic enzyme used industrially in beverage, food, pharmaceutical industries including production of chewing gums, tenderizing meat and drugs preparation for digestive ailments and treatment of gangrenous wounds [1]. According to Oloyede [5], unripe fruit helps in the contraction of the muscle fibres of the womb and is thus beneficial in securing proper menstrual flow. It is very helpful especially in case of cessation of menstruation due to exposure to cold or fright in young unmarried girls. Leaves of paw-paw plant

* Corresponding author:

E. M. Ilondu (martinailondu@yahoo.co.uk) 
are eaten as vegetables and are used in herbal preparations for the treatment of malaria and hypertension [6]. The anti-sickling properties (inhibition of Sickle cell formation) of paw-paw leaf extracts [7] and its protective effects against gastric ulcer in rats [8] have been documented.

Paw-paw plant is susceptible to a number of diseases caused by bacteria, fungi, viruses and nematodes. Commonest among them is the fungal diseases particularly leafspot [9] and post-harvest fruit rot [1]. The diseases that affect the leaves reduce the photosynthetic areas of the plant and consequently affect the food manufacturing capacity of the plant. Leafspot disease when severe, can cause $30-50 \%$ loss in infested field [10].

In recent years, multiple chemical resistance in plant pathogenic microorganisms has been developed due to indiscriminate use of commercial antimicrobial chemicals commonly used in the treatment of infectious disease. Resistance to chemotherapy have been noted in all categories of microorganisms including bacteria, fungi and viruses. One of the methods that reduce resistance to antibiotics is using antibiotic inhibitors of plant origin. Compounds isolated from edible and medicinal plants present very potent natural, biological active agents [27]. One of such plants is Aspilia africana C. D. Adams in the family of Asteraceae. It is used in African ethno-medicine for the treatment of haemorrhage [11]. The antifungal activities of A. africana on damping-off of Capsicum annuim and leafspot of sweet potato pathogens have been documented $[12,28]$. There is a continuous and urgent need to discover new antifungal compounds with diverse chemical composition and novel mechanism of action for new and re-emerging infectious plant diseases. Plants like A. africana should be investigated to understand better about their properties and efficacy in this direction. This paper therefore describes the results of GC/MS analysis of chloroform, petroleum ether and methanol extract from the leaves of A. africana and their comparative activity against paw-paw leafspot pathogens with the view of developing an ecofriendly biofungicide for use in the control of foliar diseases.

\section{Materials and Methods}

\subsection{Fungi Isolates}

Collectothricum gloesporides and Curvularia lunatus used in this study were previously isolated, identified and their pathogenicty as paw-paw (Carica papaya) leafspot disease pathogens confirmed (Ilondu unpublished). The cultures of these fungi were maintained on potato Dextros Agar (PDA) slants at $4^{\circ} \mathrm{C}$ in the laboratory until needed. The isolates were revived twice on PDA before use.

\subsection{Collection and Extraction of Plant Sample}

Aspillia africana (Pers) C.D. Adams used in this study was obtained from the premises of site I, Delta State University, Abraka. The plant was properly identified using Akobundu and Agyakwa [25] as well as from the herbarium maintained by the Department of Botany of the same University. The leaves of $A$. africana were plucked and washed in flowing tap water, shade dried on the bend in a ventilated area of the herbarium at room temperature $\left(28^{\circ} \mathrm{C}-30^{\circ} \mathrm{C}\right)$ for two weeks [13].

Dried leaves were ground into powder using electric blender (Philip Confort HR 1727) before extraction. The method of extraction was a modification of Oyewale and Audu [14]. 100g of pulverised sample was put into the Soxhlet extractor and $300 \mathrm{ml}$ of methanol was added at the ratio of 1:3 and extracted for 8 hours. This extraction procedure was same for petroleum ether and chloroform. Each batch of the extract was evaporated on a rotary evaporator at $40^{\circ} \mathrm{C}$ to remove excess solvent leaving behind the solidified extracts which were put into sterile bottles and stored in the refrigerator until needed.

\subsection{Phytochemical Screening of the Extracts}

The preliminary phytochemical screening to detect the presence of secondary metabolites such as alkaloids, flavonoids, Anthraquenones, tannins, terpenes was carried out using the standard procedures of Evans and Trease [15].

\subsection{GC-MS Analysis of Extracts}

GC-MS analysis was done at National Research Institute for Chemical Technology (NARICT), Zaria, Kaduna State, Nigeria. The extracted samples were aspirated into the GC-MS-QP2010 PLUS Shimadzu, Japan with the following machine parameters: High pumping speed, column oven temperature $60^{\circ} \mathrm{C}$, injection temperature $250^{\circ} \mathrm{C}$, injection mode split, pressure $100.0 \mathrm{kPa}$, total flow $20.7 \mathrm{ml} / \mathrm{min}$, column flow $1.61 \mathrm{ml} / \mathrm{min}$, linear velocity $46.3 \mathrm{~cm} / \mathrm{sec}$ and split ratio 10.0 . The generated chromatogram was recorded. 


\subsection{Preparation of Plant Extract-agar Medium}

For every set of experiment the plant extracts were each dissolved in a solvent, dimethyl sulphoxide (DMSO) in the ratio of $1 \mathrm{~g}$ of extract to $10 \mathrm{ml}$ of DMSO (1:10) to give the $100 \mathrm{mg} / \mathrm{ml}$ concentration [16]. Different concentrations $(20 \mathrm{mg} / \mathrm{ml}, 40 \mathrm{mg} / \mathrm{ml}, 80 \mathrm{mg} / \mathrm{ml}, 160 \mathrm{mg} / \mathrm{ml}$ and $320 \mathrm{mg} / \mathrm{ml})$ were prepared from each of the extracts. One milliliter of each level of concentration was aseptically incorporated into $20 \mathrm{ml}$ of cool molten PDA in sterile test tube. Three test tubes were used for each extract concentration and the fourth test tube without the extract served as control. Each medium was thoroughly homogenized by gentle agitation before dispensing into $9 \mathrm{~cm}$ diameter sterile Petri dishes. The plates were allowed to set on the laboratory bench for $3 \mathrm{hrs}$.

\subsection{Determination of Fungal Inhibition}

This was done by inoculating at the centre of $9 \mathrm{~cm}$ Petri plates with a mycelia disc $(4 \mathrm{~mm})$ obtained from the colony edge of 7-day old culture of the test fungi. Three replicates of both the control and PDA-extract plates per isolate were incubated at room temperature $\left(28 \pm 2^{\circ} \mathrm{C}\right)$ and radial growth was measured with a metric ruler daily for seven days. Percentage inhibition of fungal growth was calculated following Ilondu et al. [12]:

$$
\mathrm{FP}=\frac{\mathrm{dc}-\mathrm{dt}}{\mathrm{dc}} \times \frac{100}{1}
$$

where:

FP $=$ Percentage inhibition of fungal growth

$\mathrm{dc}=$ Average diameter of fungal growth in control plates

$\mathrm{dt}=$ Average diameter of fungal growth in treated plates

\subsection{Data Analysis}

Data obtained were subjected to Analysis of variance (ANOVA) using statistical package for social science SPSS version 17.0 and means were separated according to Duncan's Multiple Range Test (DMRT) at 5\% probability level.

\section{Results}

Classes of natural products present in the leaf extracts were shown in Table 1 . All the phytochemicals determined were found present in the extracts. However, alkaloids and
Table 1. Phytochemical constituents of leaf extracts of Aspilia africana

\begin{tabular}{lccc}
\hline Constituents & \multicolumn{3}{c}{ Extracts } \\
\cline { 2 - 4 } & Chloroform & Pet. & Methanol \\
& & Ether & \\
\hline Tannins & ++ & ++ & ++ \\
Glycosides & + & + & + \\
Saponins & + & + & + \\
Steroids & + & + & + \\
Flavonoids & + & + & ++ \\
Alkaloids & + & + & +++ \\
Terpenes & + & + & +++ \\
Phenols & + & + & + \\
Anthraquinones & + & + & ++ \\
\hline Key: & & & +
\end{tabular}

Key:

- = Absent

$+=$ Present

$+=$ Low concentration

$++=$ Moderate concentration

$+++=$ High concentration

terpenes were found in high concentration especially in methanol extract while anthraquinones, flavonoids and tannins occur in moderate quantity. The results of antifungal activity are presented in Table 2. All the extracts significantly $(\mathrm{p}<0.05)$ exhibited varied levels of inhibitory effect on the fungi at all concentration with a dose-dependent toxicity. At concentrations of $160 \mathrm{mg} / \mathrm{ml}$ and 320 $\mathrm{mg} / \mathrm{ml}$, methanol extractive showed $100 \%$ inhibition of growth of both pathogens (Table 3). However, C. lunatus was more sensitive to the extract than C. gloeosporioides.

GC-MS analysis revealed a complex mixture of compounds in the extracts. The gas chromatography profiles were shown in Figures 1-3. Various constituents of the extracts identified by mass spectral comparison with those of the National Institute of Standard Technology (NIST) Library were also shown in Tables 4-6. Seven compounds were identified in chloroform extract (Table 4) while eight compounds in both petroleum ether (Table 5) and Methanol (Table 6). The petroleum ether extract was characterized by the abundance of Phthalic acid di(1-hexen-5-yl) ester (24.18\%), Germacrene D (17.06\%), Beta-trans-Ocimene (15.10\%) and Phytol (11.53\%). Similarly Phthalic acid di(1-hexen-5-yl) ester (27.94\%), Germacrene D (19.72\%), Linolenic acid (14.83\%) and Phytol (13.33\%) were the main constituents in chloroform extracts while Diethyl phthalate (22.81\%), 4-(Benzyloxy)-3-methoxy-2-nitrobenzaldehyde (13.94\%), Oxydiethylene acetate (13.33\%) and (2-methyl(1,3) dioxolan-2-yl) thioacetic acid (13.32\%) 
Table 2. Effect of various extracts $(\mathrm{mg} / \mathrm{ml})$ from A. africana on the radial mycelia growth $(\mathrm{cm}) *$ of Colletotrichum gloeosporioides and Curvularia lunatus on agar plates seven days after incubation.

\begin{tabular}{ccccccc}
\hline $\begin{array}{c}\text { Extract Conc. } \\
(\mathrm{mg} / \mathrm{ml})\end{array}$ & \multicolumn{3}{c}{ Colletotrichum gloeosporioides } & \multicolumn{3}{c}{ Curvularia lunatus } \\
\cline { 2 - 7 } & Chloroform & Methanol & $\begin{array}{c}\text { Petroleum } \\
\text { Ether }\end{array}$ & Chloroform & Methanol & Petroleum Ether \\
\hline 0 & $4.30 \pm 0.0^{\mathrm{a}}$ & $4.30 \pm 0.0^{\mathrm{a}}$ & $4.30 \pm 0.0^{\mathrm{a}}$ & $4.30 \pm 0.0^{\mathrm{a}}$ & $4.30 \pm 0.0^{\mathrm{a}}$ & $4.30 \pm 0.0^{\mathrm{a}}$ \\
20 & $2.79 \pm 1.46^{\mathrm{b}}$ & $2.79 \pm 1.46^{\mathrm{b}}$ & $2.79 \pm 1.46^{\mathrm{b}}$ & $1.91 \pm 1.53^{\mathrm{b}}$ & $1.94 \pm 1.53^{\mathrm{b}}$ & $1.94 \pm 1.53^{\mathrm{b}}$ \\
40 & $1.77 \pm 1.02^{\mathrm{c}}$ & $1.13 \pm 0.12^{\mathrm{c}}$ & $1.60 \pm 0.95^{\mathrm{c}}$ & $0.99 \pm 0.84^{\mathrm{c}}$ & $0.90 \pm 0.11^{\mathrm{c}}$ & $0.86 \pm 0.56^{\mathrm{c}}$ \\
80 & $1.26 \pm 0.85^{\mathrm{d}}$ & $0.60 \pm 0.06^{\mathrm{d}}$ & $1.20 \pm 0.88^{\mathrm{d}}$ & $0.58 \pm 0.57^{\mathrm{d}}$ & $0.40 \pm 0.10^{\mathrm{d}}$ & $0.78 \pm 0.54^{\mathrm{c}}$ \\
160 & $0.8 \pm 0.65^{\mathrm{e}}$ & $0.00 \pm 0.0^{\mathrm{e}}$ & $0.80 \pm 0.52^{\mathrm{e}}$ & $0.35 \pm 0.41^{\mathrm{e}}$ & $0.0 \pm 0.0^{\mathrm{e}}$ & $0.41 \pm 0.46^{\mathrm{d}}$ \\
320 & $0.40 \pm 0.1^{\mathrm{f}}$ & $0.00 \pm 0.0^{\mathrm{e}}$ & $0.40 \pm 0.10^{\mathrm{f}}$ & $0.1 \pm 0.14^{\mathrm{f}}$ & $0.0 \pm 0.0^{\mathrm{e}}$ & $0.21 \pm 0.31^{\mathrm{d}}$ \\
\hline
\end{tabular}

*Values are means of three replicates + standard Error

Values with the same letter(s) superscript in the same column are not significantly different at $\mathrm{P} \geq 0.05$ by DMRT.

Table 3. Percentage growth inhibition of Colletotrichum gloeosporioides and Curvularia lunatus at varying concentrations of leaf extracts of Aspilia Africana after 7 days of incubation on agar plates.

\begin{tabular}{ccccccc}
\hline $\begin{array}{c}\text { Extract Conc. } \\
(\mathrm{mg} / \mathrm{ml})\end{array}$ & \multicolumn{2}{c}{ Colletotrichum gloeosporioides } & \multicolumn{3}{c}{ Curvularia lunatus } \\
\cline { 2 - 7 } & Chloroform & Methanol & $\begin{array}{c}\text { Petroleum } \\
\text { Ether }\end{array}$ & Chloroform & Methanol & Petroleum ether \\
\hline 0 & $0^{\mathrm{f}}$ & $0^{\mathrm{e}}$ & $0^{\mathrm{f}}$ & $0^{\mathrm{f}}$ & $0^{\mathrm{e}}$ & $0^{\mathrm{d}}$ \\
20 & $35.12^{\mathrm{e}}$ & $35.12^{\mathrm{d}}$ & $35.12^{\mathrm{e}}$ & $55.58^{\mathrm{e}}$ & $54.88^{\mathrm{d}}$ & $54.88^{\mathrm{c}}$ \\
40 & $58.84^{\mathrm{a}}$ & $73.72^{\mathrm{c}}$ & $62.79^{\mathrm{d}}$ & $76.98^{\mathrm{d}}$ & $79.07^{\mathrm{c}}$ & $80.00^{\mathrm{b}}$ \\
80 & $70.70^{\mathrm{c}}$ & $86.05^{\mathrm{b}}$ & $72.09^{\mathrm{c}}$ & $86.51^{\mathrm{c}}$ & $90.70^{\mathrm{b}}$ & $81.86^{\mathrm{b}}$ \\
160 & $81.40^{\mathrm{b}}$ & $100^{\mathrm{a}}$ & $81.40^{\mathrm{b}}$ & $91.86^{\mathrm{b}}$ & $100^{\mathrm{a}}$ & $90.47^{\mathrm{a}}$ \\
320 & $90.70^{\mathrm{a}}$ & $100^{\mathrm{a}}$ & $90.70^{\mathrm{a}}$ & $97.67^{\mathrm{a}}$ & $100^{\mathrm{a}}$ & $95.12^{\mathrm{a}}$ \\
\hline
\end{tabular}

*Values are means of three replicates \pm standard Error

Values with the same letter(s) superscript in the same column are not significantly different at $\mathrm{P} \geq 0.05$ by DMRT.

were the major representatives in methanol extract. It was observed that Phthalic acid di(1-hexen-5-yl) ester, Germacrene D, phytol and hexadecanoic acid occurred in chloroform and petroleum ether extracts only. Linolenic acid was identified in chloroform extracts while Beta-transocimene and Caryophylene occurred in petroleum ether extract only. All the compounds identified in methanolic extracts were unique to the extract.

\section{Discussion}

This study showed that different extracts derived from $A$. africana provided varying degree of control of the leafspot fungi studied. Antifungal activities of $A$. africana have been reported by previous workers. Adeniyi and Odufuwora [17] reported that extracts of $A$. africana showed a broad spectrum of activity against all fungal and bacterial pathogens studied. Similarly, the antifungal activities of $A$. africana extract on yam rot pathogens [18], damping-off pathogens of pepper [12]; and sweet potato leafspot fungi [28] have been reported. This work also focused on the identification of active compounds in the extracts. These extracts evaluated in this study presented complex mixtures of constituents that could be considered as answerable for the antifungal activity. The active components usually interfere with growth and metabolism of microorganisms in 

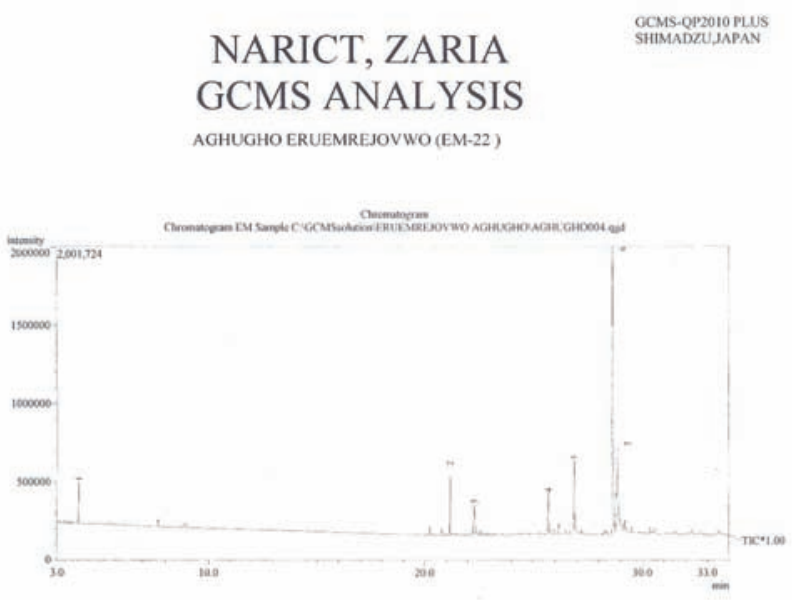

Figure 1. GC-MS Chromatogram for Petroleum ether extract of Aspilia Africana.

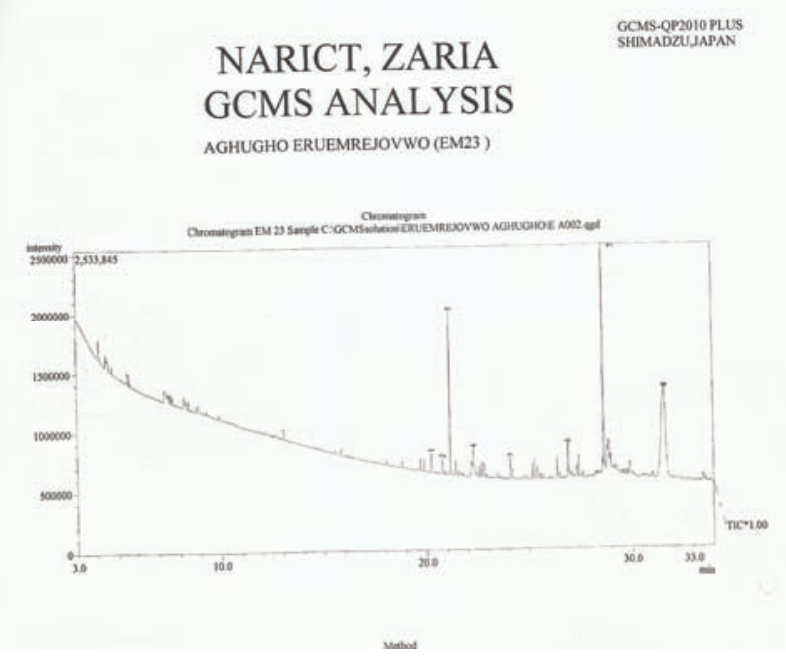

Figure 2. GC-MS Chromatogram for Petroleum ether extract of Aspilia Africana.

a negative manner [19]. Although they usually occur as complex mixtures, their activity may account for in terms of their major components. However, according to the report of Del-Vechio-Vieira et al. [20], both minor and major components as well as possible interactions between the substances could contribute to the antimicrobial properties of the extracts. The toxic effect of the extracts may have also resulted from the combined action of these constituent as reported by Ilondu [28]. The presence of these phytochmicals in the test plant are influenced by other factors such as age of plant, extracting solvent, method of extraction and time of harvesting of plant materials $[21,18$, 28]. Antifungal activity has been reported with extracts in
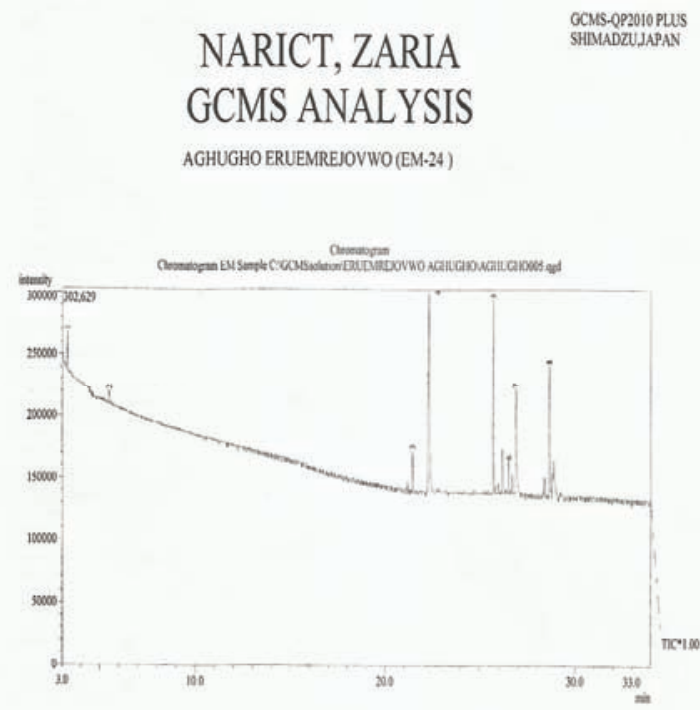

Figure 3. GC-MS Chromatogram for Methanol extract of Aspilia African.

Table 4. Major identified constituents of Chloroform extract (EM-22) of Aspilia africana

\begin{tabular}{|c|c|c|c|c|c|}
\hline $\begin{array}{c}\text { Peak } \\
\text { No }\end{array}$ & $\begin{array}{l}\text { Retention } \\
\text { time } \\
(\mathrm{min})\end{array}$ & $\begin{array}{c}\% \\
\text { Abun- } \\
\text { dance }\end{array}$ & $\begin{array}{l}\text { Molecular } \\
\text { weight }\end{array}$ & $\begin{array}{l}\text { Compound } \\
\text { formula }\end{array}$ & $\begin{array}{l}\text { Name of } \\
\text { Compound }\end{array}$ \\
\hline 1 & 4.025 & 8.06 & 114 & $\mathrm{C}_{8} \mathrm{H}_{18}$ & n-Octane \\
\hline 2 & 21.183 & 19.72 & 204 & $\mathrm{C}_{15} \mathrm{H}_{24}$ & $\begin{array}{l}\text { Germacr- } \\
\text { ene D }\end{array}$ \\
\hline 3 & 22.308 & 27.94 & 330 & $\mathrm{C}_{20} \mathrm{H}_{26} \mathrm{O}_{4}$ & $\begin{array}{l}\text { Phthalic } \\
\text { acid, di-(1- } \\
\text { hexen-5-yl) } \\
\text { ester }\end{array}$ \\
\hline 4 & 25.708 & 8.06 & 240 & $\mathrm{C}_{16} \mathrm{H}_{32} \mathrm{O}$ & $\begin{array}{l}\text { 1,2-Epoxy- } \\
\text { hexadecane }\end{array}$ \\
\hline 5 & 26.900 & 8.06 & 256 & $\mathrm{C}_{16} \mathrm{H}_{32} \mathrm{O}_{2}$ & $\begin{array}{l}\text { Hexade- } \\
\text { canoic acid }\end{array}$ \\
\hline 6 & 28.650 & 13.33 & 296 & $\mathrm{C}_{20} \mathrm{H}_{40} \mathrm{O}$ & Phytol \\
\hline 7 & 28.883 & 14.83 & 278 & $\mathrm{C}_{18} \mathrm{H}_{30} \mathrm{O}_{2}$ & $\begin{array}{l}\text { Linolenic } \\
\text { acid }\end{array}$ \\
\hline
\end{tabular}

plants belonging to Asteraceae family [17, 20, 18, 12, 22]. Probably similar components such as those detected in this study could be responsible for this property. For instance Lee et al. [26] reported that linolenic acid has a strong antimicrobial activity against Bacillus cereus and Staphylococus aureus. Yoshihiro et al. [29] reported that three diterpene which, included phytol showed antimicrobial effect on Staphylococus aureus. Phytol caused inhibitory effects on the pathogen by damaging the cell membrane to allow the 
Table 5. Major identified constituents of Petroleum ether extract (EM-23) of Aspilia africana

\begin{tabular}{|c|c|c|c|c|c|}
\hline $\begin{array}{c}\text { Peak } \\
\text { No }\end{array}$ & $\begin{array}{l}\text { Retention } \\
\text { time } \\
(\mathrm{min})\end{array}$ & $\begin{array}{c}\% \\
\text { Abun- } \\
\text { dance }\end{array}$ & $\begin{array}{l}\text { Com- } \\
\text { pound } \\
\text { formula }\end{array}$ & $\begin{array}{c}\text { Molecular } \\
\text { weight }\end{array}$ & $\begin{array}{l}\text { Name of } \\
\text { Compound }\end{array}$ \\
\hline 1 & 20.242 & 6.65 & $\mathrm{C}_{15} \mathrm{H}_{24}$ & 204 & $\begin{array}{l}\text { 4,11,11- } \\
\text { Trimethyl- } \\
\text { 8-methylene } \\
\text { bicyclo } \\
(7.2 .0) \\
\text { undec-4-ene }\end{array}$ \\
\hline 2 & 20.783 & 15.10 & $\mathrm{C}_{10} \mathrm{H}_{16}$ & 136 & $\begin{array}{l}\text { Beta-trans- } \\
\text { Ocimene }\end{array}$ \\
\hline 3 & 21.183 & 17.06 & $\mathrm{C}_{15} \mathrm{H}_{24}$ & 204 & $\begin{array}{l}\text { Germacrene } \\
\text { D }\end{array}$ \\
\hline 4 & 22.300 & 24.18 & $\mathrm{C}_{20} \mathrm{H}_{26} \mathrm{O}_{4}$ & 330 & $\begin{array}{l}\text { Phthalic acid, } \\
\text { di-(1-hexen- } \\
\text { 5yl) ester }\end{array}$ \\
\hline 5 & 24.092 & 9.25 & $\mathrm{C}_{16} \mathrm{H}_{34}$ & 226 & Hexadecane \\
\hline 6 & 26.900 & 6.98 & $\mathrm{C}_{16} \mathrm{H}_{32} \mathrm{O}_{2}$ & 256 & $\begin{array}{l}\text { Hexade- } \\
\text { canoic acid }\end{array}$ \\
\hline 7 & 28.650 & 11.53 & $\mathrm{C}_{20} \mathrm{H}_{40} \mathrm{O}$ & 296 & Phytol \\
\hline 8 & 31.625 & 9.26 & $\mathrm{C}_{34} \mathrm{H}_{70}$ & 478 & $\begin{array}{l}\text { Tetratriac- } \\
\text { ontane }\end{array}$ \\
\hline
\end{tabular}

leakage of $\mathrm{K}^{+}$ions from the cell. Fatty acid and their methyl esters have been shown to have antibacterial and antifungal properties [23]. Del-Vechio-Vieira et al. [20] reported the abundance of Germacrene D in the leaf oil of Ageratum fastigiatum and was considered as responsible for the antimicrobial activity of the oil. The antimicrobial activity of the stem of Mallotus philippensis Var. Philippenses have been reported by Veanganni et al. [19]. According to them, the GC-MS analysis of the ethanol extract of this plant revealed the major component among organic esters as diethyl phthalate. The observed differences in the fungitoxic ability of the extracts used in this study may be attributed to the solubility of the phytochemicals in the extracting solvent and susceptibility of the test fungi to various concentrations of the extracts. This also agrees with the findings of Onifade [24], Okigbo and Odurukwe [18] and Ilondu [28].

\section{Conclusion}

The results of this study are suggestive of toxic potency of A. africana which could be harnessed as a source of antifungal agent especially its methanol extract. However, further studies are required to evaluate the phytotoxicity of these extracts for field applications. This will be of
Table 6. Major identified constituents of Methanol extract (EM-24) of Aspilia africana

\begin{tabular}{|c|c|c|c|c|c|}
\hline $\begin{array}{l}\text { Peak } \\
\text { No }\end{array}$ & $\begin{array}{l}\text { Retention } \\
\text { time } \\
(\min )\end{array}$ & $\begin{array}{c}\% \\
\text { Abun- } \\
\text { dance }\end{array}$ & $\begin{array}{l}\text { Com- } \\
\text { pound } \\
\text { formula }\end{array}$ & $\begin{array}{c}\text { Molecular } \\
\text { weight }\end{array}$ & $\begin{array}{l}\text { Name of } \\
\text { Compound }\end{array}$ \\
\hline 1 & 3.275 & 13.33 & $\mathrm{C}_{8} \mathrm{H}_{14} \mathrm{O}_{5}$ & 190 & $\begin{array}{l}\text { Oxydiethylene } \\
\text { acetate }\end{array}$ \\
\hline 2 & 5.492 & 13.94 & $\mathrm{C}_{15} \mathrm{H}_{13} \mathrm{NO}_{5}$ & 287 & $\begin{array}{l}\text { 4-(Benzyloxy)- } \\
\text { 3-methoxy- } \\
\text { 2-nitroben- } \\
\text { zaldehyde. }\end{array}$ \\
\hline 3 & 21.458 & 8.73 & $\mathrm{C}_{8} \mathrm{H}_{18} \mathrm{Cl}_{2} \mathrm{P}_{2}$ & 246 & $\begin{array}{l}\text { 1,2-ditert-butyl- } \\
\text { 1,2-dichlorodi- } \\
\text { phosphane. }\end{array}$ \\
\hline 4 & 22.308 & 22.81 & $\mathrm{C}_{12} \mathrm{H}_{14} \mathrm{O}_{4}$ & 222 & $\begin{array}{l}\text { Diethyl } \\
\text { Phthalate }\end{array}$ \\
\hline 5 & 25.708 & 10.42 & $\mathrm{C}_{15} \mathrm{H}_{30} \mathrm{O}$ & 226 & Pentadecanal \\
\hline 6 & 26.508 & 13.32 & $\mathrm{C}_{13} \mathrm{H}_{20} \mathrm{O}_{6} \mathrm{~S}$ & 304 & $\begin{array}{l}\text { (2-methyl }(1,3) \\
\text { dioxolan-2-yl) } \\
\text { thioacetic acid, }\end{array}$ \\
\hline 7 & 26.908 & 6.58 & $\mathrm{C}_{5} \mathrm{H}_{11} \mathrm{NO}_{2}$ & 117 & Amyl nitrite \\
\hline 8 & 28.650 & 10.88 & $\mathrm{C}_{16} \mathrm{H}_{34} \mathrm{O}$ & 242 & Dioctyl ether \\
\hline
\end{tabular}

great importance to guide effective use of such plants by farmers against foliar diseases of various crops especially paw-paw.

\section{Acknowledgements}

The Author is grateful to the Director, National Research Institute for Chemical Technology (NARICT)Zaria, Kaduna State, Nigeria, for the GC-MS analysis of the extract and to Pastor Aghoghome F. Eruemrejovwo, Chief Technologist, Department of Chemistry, Delta State University, Abraka, for his assistance in the plant extraction.

\section{References}

1. Ilondu E M (2011). Evaluation of some aqueous plant extracts used in the control of pawpaw fruit (carica papaya L.) rot fungi, Journal of Applied Biosciences, vol 37, 2419-2424.

2. Oluma H O A, and Oladiran A O (1993). Phythium aphanidermatum root-rot of paw-paw (Carica papaya) in Nigeria, Mycopathology, vol 123(2), 111-115. 
3. Adetunyi V O, and Salawu O T (2008). West African soft cheese processed with Calotropis procera and Carica papaya, A comparative assessment of nutritional values, African Journal of Biotechnology, vol 7(18), 3360-3362.

4. Krishna K L, Paridhavi M et al. (2008). Review of nutritional, medicinal and pharmacological properties of papaya (Carica papaya L.), National Product Radiance, vol 7(4), 364-373.

5. Oloyede O I (2005). Chemical profile of unripe pulp of Carica Papaya, Pakista Journal of Nutrition, vol 4(6), 379381

6. Adodo A (2004). Nature Power, $3^{\text {rd }}$ Edn., OSB Ewu-Esan, Nigeria.

7. Imaga N O A, Gbenle G O et al. (2009). Antisickling property of Carica Papaya leaf extract, African Journal of Biochemical Research, vol 3(4), 102-106

8. Indran M, Mahmood A A et al. (2008). Protective effect of Carica papaya L. leaf extract against alcohol induced acute gastric damage and blood oxidative stress in rats, West Indian Medical Journal, vol 57(4), 323-326.

9. Desmond Y O, and Ronald A H (2001). Blackspot papaya disease: New pest advisory notes. In: Horn C W (Ed), Pland Disease handbook, Agricultural Diagnostic Service Centre, College of Tropical Studies, Honolulu, Hawaii, 125-128.

10. Mehrotra R S, and Aggarwal A (2003). Plant Pathology, $2^{\text {nd }}$ Edn, Tata McGraw-Hill Publishing Company Limited, New Delhi.

11. Katsayal U A (2002). Pharmacognostic studies on the leaves of Aspilia Africana, Nigerian Journal of Botany, vol 15, 62-67.

12. Ilondu E M, Ayodele S M et al. (2010). Etiology and control of damping- off disease of pepper (Capsicum annum) with powdered leaves of three Asteraceous plants, Nigerian Journal of Plant Protection, vol 24, 75-81.

13. Rai M K, and Acharya D (1999). Screening of some Asteraceous plants for antimycotic activity, Compositae Newsletter, vol 34, 37-43.

14. Oyewale A O and Audu O T (2007). The medicinal potentials of aqueous and methanol extracts of six flora of tropical Africa, Journal of Chemical Society of Nigeria, vol 32(1), $150-155$

15. Evans W C, and Trease G E (1999). Pharmacognosy, W B Sunders Company Limited, Notingham, U.K. 310-315.

16. Onyeke C C, and Maduewesi J N C (2006). Evaluation of some plant extracts for the control of post-harvest fungal diseases of Banana (Musa sapientum L.) fruit in SouthEastern Nigeria, Nigerian Journal of Botany, vol 19(1), 129-137.

17. Adeniyi B A, and Odufowora R O (2000). In-vitro Antimicrobial properties of Aspilia africana (Compositae), African Journal of Biomedical Research, vol 3, 167-170
18. Okigbo R N, and Odurukwe C N (2009). Occurrence and control of fungal rot pathogen of yam (Dioscorea rotundata Poir) with leaf extracts of Chromolaena odorata, Carica papaya and Aspilia Africana, Nigerian Journal of Mycology, vol 2(1), 154-165.

19. Velanganni J, Kadamban D et al. (2011). Phytochemical screening and antimicrobial activity of the stem of Mallotus philippensis (Lam.) Muell. Arg. Var. Philippensis (Euphorbiaceae), International Journal of Pharmacology and Pharmaceutical Sciences, vol 3(Suppl.2), 160-163.

20. Del-Vechio-Vieira G, Sousa O V et al. (2009). Chemical composition and antimicrobial activity of essential oils of Ageratum fastigiatum (Asteraceae), Records of Natural Products, vol 3(1), 52-57.

21. Okungbowa F I, and Edema N E (2007). Antifungal activities of leaf extracts from six Asteraceous plants against Fusarium oxysporium, Nigeria Journal of Botany, vol 20(1), 45-49.

22. Okoi A I, and Afuo C O (2009). Effects of leaf extracts of three plant species on Cercospora arachidicola Hori, the causal fungus of leafspot disease of Groundnut (Arachis hypogea L.), Nigerian Journal of Plant Protection, vol 23, 63-70.

23. Agoramoorthy G, Chandrasekaran M et al. (2007). Antibacterial and Antifungal activities of fatty acid methyl esters of the Blind-your-eye Mangrove from India, Brazilian Journal of Microbiology, vol 38, No. 4, 739-742.

24. Onifade A K (2002). Antifungal effect of Azadirachta indica A. Juss extracts on Collectotricm lindemathianum, Global Journal of Pure and Applied Sciences, vol 6(3), 423-428.

25. Akobundu I O, and Agyakwa C W (1998). A Handbook of West African Weeds, $2^{\text {nd }}$ Edn., International Institute of Tropical Agriculture, Ibadan, Oyo State, Nigeria.

26. Lee J Y, Kim Y S et al. (2002). Antimicrobial synergistic effect of Linolenic acid and monoglyceride against Bacillus cereus and Staphylococcus aureus, Journal of Agriculture and Food Chemistry, vol 50(7), 2193-2199.

27. Vukovic N, Sukdolak S et al. (2011). Chemical composition and antimicrobial activity of Teucrium arduini essential oil and cirsimarin from Montenegro, Journal of Medicinal Plant Research, vol 5(7), 1244-1250.

28. Ilondu E M (2012). Etiology and Management of leafspot disease of sweet potato (Ipomoea batatas (L) Lam) in Delta State, Nigeria Ph.D Thesis Department of Agronomy, Faculty of Agriculture Delta State University, Asaba campus.

29. Yashihiro I, Toshiko $\mathrm{H}$ et al. (2005). Biphasic effects of Geranylgeraniol, Teprenone and Phytol on the growth of Staphylococcus aureus, Antimicrobial Agents and Chemotherapy, vol 49(5), 1770-1774. 